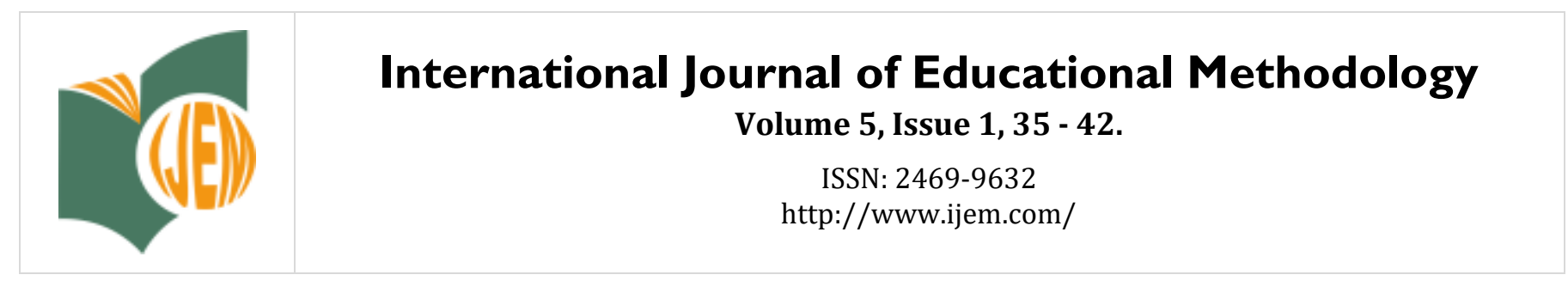

\title{
Sixth Grade Students' Listening Comprehension of the Story Text
}

\author{
Ozgur Babayigit* \\ Yozgat Bozok University, TURKEY
}

Received: December 4, 2018 - Revised: December 24, 2018 - Accepted: December 28, 2018

\begin{abstract}
The aim of this research is to investigate ability of sixth grade students' comprehension the listened story text. The research is the survey type of quantitative research methods. The population of the study consisted of the sixth grade students of the middle schools in the city center of Yozgat, Turkey in the 2018-2019 academic years. A simple random cluster sampling method was used in the selection of the sample. A total of 369 sixth grade students are sample. As a data collection, a story text entitled "Hero of the Town" was used. Data were collected in October 2018. SPSS 21 program was used to analyze the data. The level of listening comprehension the sixth grade students to the story text is $77.46 \%$. It is seen that the sixth grade girl students' listening comprehension are better than boy students. The girls' listening comprehension is higher than boys' \% 8 .
\end{abstract}

Keywords: Secondary school, listening, comprehension.

To cite this article: Babayigit, 0. (2019). Sixth grade students' listening comprehension of the story text. International Journal of Educational Methodology, 5(1), 35-42. https://doi.org/10.12973/ijem.5.1.35

\section{Introduction}

The listening ability in the individual begins in the mother's womb (Yaylı et al., 2008, p. 77). In this respect, the first basic language skill of the individual is listening (Celenk, 2007, p. 127; Erdogan, 2013, p. 138). Listening skills develop in time. It is aimed to develop listening skills during school years. In the introduction part of this research, the concept of listening is explained. Then the importance of listening was emphasized. Finally, listening education is explained.

\section{Listening}

Listening is a complex multi-step process in which spoken language is interpreted in the mind (Lundsteen, 1979, p. 14; Tompkins \& Hoskisson, 1995, p. 83). Listening is the ability of become meaningful by the brain after the fluctuations in the air pressure (Smith \& Kosslyn, 2017, p. 496). 5). Listening, in a loud message is the ability to correctly understand the verbal messages desired (Koc, 2008, p. 450; Yuksel, 2013, p. 174). Taking the sound stimuli into consideration, it is an effort to make them overlap the sounds in our memory (Ungan, 2014, p. 136). It is the activity of the speaker to understand smoothly and to be able to react against the stimulus (Demirel \& Sahinel, 2006, p. 72). Listening is a complex process in which sound and speeches are structured in the mind by means of meaning (Ministry of National Education, 2009, p. 13; Gunes, 2007, p. 71). The main purpose of listening is to be able to understand the message, emotions and thoughts that the speaker wants to convey as accurately as we can say that these are close together and complementary. A listening activity without understanding remains only hearing. Hearing is a physiological process that ends with the reaching of sound signals to the brain; listening is a mental process that involves hearing. In the hearing, the sound elements are perceived by the ear, and in the listening, the perceived sound elements are combined and associated with each other (Ozbay \& Keles, 2011, p. 158).

Listening is an active process. Listening requires many different elements to require mastery, for example: physically adjusting; to pay attention to the whole time the speaker speaks; voice intonation, highlighting and noting the phrase; monitor body language cues (such as eye movements); distinguish between original and rhetorical questions; combining humor and metaphor; and the vocabulary used by the speaker. In addition, the listener himself brings with it previous experiences, emotions and tendencies that affect the way in which the words of the speakers are heard and interpreted (Hayes, 2010, p. 261). Listening is not automatic. Sometimes hear, but don't listen. Sometimes do not listen intentionally and avoid listening to things. In other words, while listening sounds are related to making and clarifying the code of messages, hearing only consists in the transmission of sound waves to the brain with certain hearing aids

\footnotetext{
* Correspondence:

Ozgur Babayigit, Yozgat Bozok University, Department of Primary Education, Turkey.

$\bowtie$ ozgur.babayigit@bozok.edu.tr
} 
(Yuksel, 2015, p. 125). In daily life, spend more time listening than reading, speaking and writing (Gurgen, 2008, p. 49). Attention is very important in listening. It is a fact that during listening, people can only concentrate their attention at peak times. Apart from that, attention varies and may decrease and increase in connection with the listening period (Koc \& Muftuoglu, 2015, p. 57). It is important to remember that experiences, knowledge and vocabulary play a role in listening to what hear (Gurgen, 2008, p. 50). Another factor that reduces attention is the degree of interest of the person in the subject. The person cannot give too much attention to a subject that he/she is not interested in (Koc \& Muftuoglu, 2015, p. 57). Listening is one of the basic ways of communicating and learning, and it is the ability to correctly understand, interpret and evaluate the given message. The widespread use of visual and audio tools in all areas of life and the use of these tools in education require an effective listening education (Ministry of National Education, 2006, p. 5). Children begin with listening to the language learning process. Listening; speaking, reading, writing forms the basis for skills with other learning areas such as visual reading and presentation. Listening skills make it easier for students to communicate, learn and develop their mental structure. Children use listening skills to learn and develop their mental structures (Ministry of National Education, 2009, p. 14).

\section{Importance of Listening}

It is very important for the teacher to read stories according to the children's level of interest and understanding loudly in the classroom, then to talk about these stories and to give students listening pleasure and habit (Aktas \& Gunduz, 2002, p. 248). Listening is an important activity used in every aspect of life and constitutes the basic step of healthy communication in social life and learning and success in school life. With the rapid development and change of science and technology, the use of visual and auditory tools increases every day, and the time devoted to listening becomes more (Ozbay \& Keles, 2011, p. 156). Listening is one of the learning processes. Learning through effective listening is faster and easier. Therefore, listening activity is an important activity in providing learning (Aktas \& Gunduz, 2002, p. 247; Alperen, 2001, p. 17; Yaylı et al., 2008, p. 79; Demirel \& Sahinel, 2006, p. 72; Gurgen, 2008, p. 49; Kaya, 2018; p. 20; Ungan, 2014, p. 137).

Listening skills are learned, such as speaking, writing and reading. Most of the time, listening is kept identical to not making a sound when someone is talking. However, it is really hard to listen, complex and a hearing dimension to learn. Proper listening is carried out by few people who know this work (Yuksel, 2015, p. 126). Listening is the most commonly used language skill throughout life (Koc, 2008, p. 450). Listening is one of the most important elements of understanding as a skill we use throughout our lives (Yaylı et al., 2008, p. 77; Dogan, 2013, p. 156; Yalcin, 2002, p. 45). Listening; the organizer of relations and communication between individuals in social life is the key to understanding, learning and success in school life. An individual with the ability to listen, understands and learns the information he/she has encountered throughout his/her education life much better than an individual who has no listening skills. Therefore s/he becomes more successful; by understanding the feelings and thoughts of the people around him in his social life; communicates with them more easily and healthily (Ozbay \& Keles, 2011, p. 157). In addition to listening, understanding, knowledge, and liking, it is also etiquette. The existence of a healthy and good environment in daily life, social life depends on the presence of people who know how to listen (Koc \& Muftuoglu, 2015, p. 55). Individuals who have not passed the listening education or who have not acquired this habit are experiencing various problems in understanding and explaining. When the person does not understand what the other person is saying, s/he goes directly to the defense and says that the fault is not the person who is speaking but the person who is speaking. This situation prevents the formation of a healthy communication environment (Ozbay \& Keles, 2011, p. 158).

\section{Listening Education}

One of the most neglected subjects in primary education in Turkey is listening education (Akyol, 2013, p. 11; Aydin Yilmaz, 2007, p. 48). When look at the amount of time and attention given to each of the four language areas in the textbooks, the teacher's guides and the curriculum guides, listening is finally (Temple \& Gillet, 1989, p. 52). Developing listening skills is a process that covers all the education periods of the person (Koc \& Muftuoglu, 2015, p. 58). The fact that both the first learned skill and the first learning in all areas are generally based on listening reveals that this skill should be included in the main language teaching (Sahin, 2011, p. 179). Listening can be improved with good education and practice (Temple \& Gillet, 1989, p. 98). There are several reasons for neglecting listening skills in schools. First of all, the majority of teachers assume that students have listening skills when they come to school. Due to this assumption, very few teachers focus on strategies that can be useful to their students in effective listening. In addition, some teachers spend much of their time on reading and writing education because they find the development of reading and writing skills more important. They put their listening and speaking skills back into the background (Tuzel \& Keles, 2013, p. 28). The teacher should devote time to the listening education; students should read poems, tale, stories (Gurgen, 2008, p. 56). Children should be trained to finish listening before they start talking. However, it is not easy to realize this situation (Hayes, 2010, p. 262).

It is estimated that the average elementary school student is expected to listen for about two and a half hours a week, so it is not surprising that some children lose their concentration (Hayes, 2010, p. 262). In listening, mental activity is faster than speaking. Mind can listen to 500 words while speaking 150 words in a minute (Gurgen, 2008, p. 53). While listening power varies from person to person, it increases in every period starting from childhood. For example, 1-5th 
listening span in the classroom, 3-20 minutes, 6-8th grades can rise to 30-40 minutes (Koc \& Muftuoglu, 2015, p. 58). Graduates of the class can understand the cause and effect relationship, and can grasp the subject in the best way (Koc \& Muftuoglu, 2015, p. 58). Listening shows ups and downs throughout the course. It is impossible for students to be at the same level of listening (Gurgen, 2008, p. 50). The students' understanding of what they listen to and their structuring in their minds are the most important stages of the listening process. For this purpose, students can revitalize what they listen to, research the meaning of the words they do not know, the subject of what they listen, the main idea, classify, question, establish a relationship, make inferences, estimate, summarize, evaluate, share with friends (Ministry of National Education, 2009, p. 14). To understand exactly what the person is saying, without adding anything to the message or skipping some of the elements of the message may be considered as the final point to be reached in listening education (Dogan, 2016, p. 6).

Various research have been conducted to listening comprehension. As a result of the research conducted by Aarnoutse, Van Den Bos \& Brand-Gruwel (1998), the results indicated significant program effects on strategic listening and strategic reading posttests, and the results were maintained on retention tests that were administered three months after termination of the program. As a result of the research conducted by Badian (1999), it was concluded that defining reading comprehension disability in terms of a discrepancy between listening and reading comprehension provides a fairly accurate estimate of the stability, gender ratio, and prevalence of the disorder. As a result of the research conducted by Brand-Gruwel, Aarnoutse \& Van Den Bos (1998), analyses of each variable indicated significant main effects for school types (children from elementary schools perform better than children from special schools), listening levels (normal listeners perform better than poor listeners), and time of testing (there was a general progress from pretests through retention tests). As a result of the research conducted by Carlisle \& Felbinger (1991), results showed significant differences between groups on the listening and on the reading subtests. As a result of the research conducted by Coyne, Zipoli, Richard, Chard, Faggella-Luby, Ruby, Santoro \& Baker (2009), suggests that direct instruction principles are effective in supporting students with varied achievement levels and that these principles can be used to enhance comprehension among students at very different points in reading development. As a result of the research conducted by Crain-Thoreson (1996), in the listening task, all groups showed phonemic confusion in gist recall scores, but prereaders were less likely than readers to exhibit susceptibility to phonemic confusion in verbatim recall scores. As a result of the research conducted by Diakidoy, Stylianou, Karefillidou \& Papageorgiou (2005) in the case of expository text, the relationship between listening and reading comprehension was weaker than the corresponding one with narrative text, and performance levels were comparable across all elementary grades. Moreover, reading comprehension levels were higher than listening comprehension levels in Grade 8, regardless of text type. As a result of the research conducted by Kintsch \& Kozminsky (1977), students tended to include a little more idiosyncratic detail in their summaries after listening than after reading, but the shared content of the summaries remained remarkably unchanged. As a result of the research conducted by Lehto \& Anttila (2003), girls systematically scored higher than boys on all measures of listening comprehension although this sex difference was small and mostly nonsignificant. As a result of the research conducted Sinatra (1990), as measured by reaction times, the visual comparison was significantly faster when subjects first heard a matching auditory stimulus for sentences, syntactic nonsense strings, and random words, but not for nonwords. As a result of the study conducted by Yildirim, Yildiz, Ates \& Rasinski (2010), the level of listening comprehension of the story text the fifth grade students in primary education was determined as arithmetic average $(\bar{x}=10.43, \mathrm{SD}=2.39)$. The present study measures the rate of understanding that the sixth grade students' listening comprehension. It also measures the rate of listening comprehension to girls and boys. Listening comprehension is few studied in Turkey.

\section{Methodology}

\section{Research Goal}

The aim of this research is to investigate the ability of sixth grade students' comprehension the listened story text. It is possible to realize listening skills, listening comprehension, different methods and different contents. Listening ability is very difficult to measure (Yalcin, 2002, p. 45). The limitation of this research is to understand that it is listening with the story text. The research is important in terms of contributing to the research of listening language skills, which have gained importance in recent years in our mother tongue education. The results of the research are important for the primary school and mother language teachers, to give insight to the researchers working in the field of listening education.

\section{Research Model}

The research is the survey type of quantitative research methods. Survey research is a quantitative type of research in which a researcher applies a questionnaire to describe their attitudes, views, behaviors, or characteristics in a sample or universe. The researcher collects quantitative data using surveys or interviews and statistically analyzes the data to identify trends and test research questions or hypotheses about responses to questions. S/He also interprets the results of the statistical test by linking the results of previous research with the meaning of the data (Creswell, 2012, p. 376). In this study, the survey method was preferred because the sixth grade students were studied listening comprehension the story text. 
Sample

The population of the study consisted of the students in the sixth grade of the middle schools in the city center of Yozgat, Turkey in the 2018-2019 academic years. A simple random cluster sampling method was used in the selection of the sample. In the cluster sampling, the current groups and then some of these groups are randomly selected (McMillan \& Schumacher, 2006, p. 123). Five secondary schools in Yozgat city center were identified by cluster sampling method. A total of 369 students is the sample. Demographic characteristics of the students in the sample are presented in Table 1.

Table 1. Demographic characteristics of the sample

\begin{tabular}{lcc}
\hline Gender & Frequency (f) & Percent (\%) \\
\hline Boy & 201 & 54,5 \\
Girl & 168 & 45,5 \\
\hline Total & 369 & 100 \\
\hline
\end{tabular}

When Table 1 is examined, it is seen that $45.5 \%$ of the students in the sample are girl and $54.5 \%$ are boy.

\section{Data Collection Tools}

As an instrument of collecting data, a story text entitled "Hero of the Town" was used. This text is prepared to measure the understanding of listening. In this measurement tool, there is a text called "Hero of the Town" with 336 words. The story text is appropriate to the level of students. Expert opinions are received for text. The following questions were asked about the story text:

Question 1) In which country is the story?

Question 2) What did the people of this country do to prevent the land from invading?

Question 3) How old is Hans?

Question 4) What is Hans's brother's name?

Question 5) Which of the brothers is the big brother?

Question 6) What did the brothers see when playing?

Question 7) Why did Hans ask for help?

Question 8) How did Hans first ask for help?

Question 9) Why did no one come from Hans's help?

Question 10) Where did Hans send his brother?

Question 11) What did Hans do after he sent his brother?

Question 12) What has forced Hans the most?

Question 13) Who was running in front?

Question 14) What did Hans say, asking those who came to help shout that we were holding up?

Question 15) What did they say to Hans after the repair was over?

\section{Data Collection}

Data were collected in October 2018. First of all, permission was obtained from Yozgat Provincial Directorate of National Education. Then the school principals were contacted. Data collection was carried out under the auspices of the deputy school principals. The data collection process lasted two weeks. Data collection was done in Turkish lessons. First, the researcher introduced himself to Turkish teacher. Then he introduced himself to the students and gave brief information about the research. The form containing questions about the story text "Hero of the Town" was distributed to the students. The Turkish teacher gave voice reading to students once. The text was read aloud in four minutes. The forms completed by the students were collected by the researcher. Data collection tools were not applied to students who are absent.

\section{Data Analyze}

SPSS 21 program was used to analyze the data. There are 15 questions. One correct answer was given to one point in the "Hero of the Town" questionnaire. The wrong answer was given zero point. No answer was evaluated as wrong answers and zero point was given. Thus, a score of 0-15 points for each student was obtained. The maximum point is 15. The minimum point is 0 . Then, the listening comprehension scores were entered into the SPSS 21 program. Thus, a 
369-line, 2-column data set was created. Frequency, percentage, average, independent samples t test techniques were used in data analysis.

\section{Findings}

The descriptive statistics of the sixth grade students in the secondary school are presented in Table 2.

Table 2. Listening comprehension of sixth grade students descriptive statistics

\begin{tabular}{lccccc}
\hline & $\mathbf{N}$ & Minimum & Maximum & Mean $(\bar{x})$ & Std. Deviation \\
\hline Listening comprehension score & 369 & 2.00 & 15.00 & 11.62 & 2.74 \\
\hline
\end{tabular}

When Table 2 is examined, it is seen that there are $\mathrm{n}=369$ middle school sixth grade students listening comprehension scores. The listening comprehension has a minimum score of 2 . The highest score is 15 . The mean listening comprehension score is $\bar{x}=11.62$. The standard deviation is $\mathrm{SD}=2.74$. In other words, the level of listening comprehension of the sixth grade students in the middle school the story text is $77.46 \%$.

Table 3 shows the results of the independent samples t test results of the listening comprehension scores of the sixth grade students.

Table 3. Comparison of sixth grade listening comprehension scores by gender

\begin{tabular}{lcccccccc}
\hline Gender & $\mathbf{n}$ & Mean & $\begin{array}{c}\text { Std. } \\
\text { Deviation }\end{array}$ & $\mathbf{t}$ & $\mathbf{d f}$ & $\mathbf{p}$ & $\begin{array}{c}\mathbf{9 5 \%} \text { Confidence } \\
\text { Interval }\end{array}$ & Effect size \\
\hline Boy & 201 & 11.07 & 2.92 & -4.32 & 367 & .001 & Lower:-1.76 Upper:-.66 & Cohen's d=.45 \\
Girl & 168 & 12.28 & 2.35 & -4.40 & 367 & & \\
\hline
\end{tabular}

When Table 3 is examined, it is seen that the mean of the listening comprehension scores the story text of boy students is $\bar{x}=11.07$. In other words, the rate of listening to boy students is $74 \%$. The mean score of the girl students' listening comprehension the story text score is $\bar{x}=12.28$. In other words, the mean score of the girl students listening comprehension is $82 \%$. It is seen that the sixth grade girl students are better at listening comprehension than boy students. At an alpha of .01, the analysis indicated a statistically significant difference among the groups, $t_{(369)}=4.32$, $p=.001$. Cohen $d$ coefficient was used for the t test to determine the effect size of the findings that are significant from the comparison tests. As a result of the calculation, Cohen's d=0.45. Cohen's d coefficient interpreted as a small size of $0.2-0.5$, a medium between $0.5-0.8$, and a magnitude greater than 0.8 (Cohen, 1988). In this case the moderate effect has been tested. The girls' listening comprehension is higher than boys' $\% 8$.

\section{Discussion and Conclusion}

In this study, the listening comprehension of the story text of the sixth grade students in the secondary school was examined. As a result of research, the sixth grade students' listening comprehension to the story text is $77.46 \%$. As a result of the research conducted by Diakidoy, Stylianou, Karefillidou \& Papageorgiou (2005, p. 63), sixth grade students' listening comprehension is $75 \%$. This result is supports present study. As a result of the research conducted by Hedrick \& Cunningham (1995, p. 432), fourth grade listening comprehension ability is $63 \%$. As a result of the research conducted by Bulut (2013), the rate of listening comprehension fourth grade students was found 60.01\%. As a result of the study conducted by Yildirim, Yildiz, Ates \& Rasinski (2010), the level of comprehension of the story text listening comprehension to the fifth grade students was determined as arithmetic average $(\bar{x}=10.43, \mathrm{SD}=2.39)$. As a result of the calculation, it was determined as $69.53 \%$. As a result of the research conducted by Aytan (2011), the rate of listening comprehension of the sixth grade students in the secondary school was found $62.6 \%$. As a result of the research conducted by Ceran (2015), the rate of listening comprehension of the sixth grade students in the secondary school was determined as 62.73\%. As a result of the research conducted by Bostanci \& Ceran (2015), the listening comprehension rate of the sixth grade students in the secondary school was found 58\%. As a result of the research conducted by Sevim \& Turan $(2017$, p. 7$)$, the rate of listening comprehension of the sixth grade students in the secondary school was $65 \%$. When the related researches are examined, it is understood that the rate of comprehension of primary school students varies between $62 \%$ and $77 \%$. The reason for this difference may be the characteristics of the student, the comprehension text.

As a result of the study, the rate of listening comprehension to boy students' is $74 \%$. The mean score of the girl students' listening comprehension is $82 \%$. It is seen that the sixth grade girl students are better at listening comprehension than boy students. And this is significant. As a result of the calculation, Cohen's $d=0.45$. In this case the moderate effect has been tested. The girls' listening comprehension is higher than boys' $8 \%$. As a result of the research conducted by Yildiz \& Cecen (2015), it was determined that there was no significant difference in terms of the meaning of the story texts in the sixth grade according to gender. As a result of the research conducted by Arslan (2013, p. 71), it was concluded that there is no significant difference between the seventh grade boys and girls in primary education in terms of their listening comprehension. When the related researches are examined, it is understood that there is no 
significant difference between the comprehension skills of boy and girl students. But, as a result of this study, the rate of listening comprehension of the sixth grade girl students was found significantly different from the boy students. As a result of the research conducted by Lehto \& Anttila (2003), girls systematically scored higher than boys on all measures of listening comprehension although this sex difference was small and mostly nonsignificant.

The following suggestions are made within the scope of the research results:

- It is suggested that listening texts should be included in the mother tongue education programs.

- Classroom teachers and native language teachers are advised to do more activities for listening education.

- The listening comprehension with the different types of texts can be studied with future research.

- The listening comprehension can be studied of students with different grades.

\section{References}

Aarnoutse, C., Van Den Bos, K. P., \& Brand-Gruwel, S. (1998). Effects of listening comprehension training on listening and reading. The Journal of Special Education, 32(2), 115-126. doi:10.1177/002246699803200206.

Aktas, S., \& Gunduz, O. (2002). Written and oral expression (3rd ed.). Ankara: Akcag Printing Publishing Marketing.

Akyol, H. (2013). Turkish teaching methods (6th ed.). Ankara: Pegem Academy.

Alperen, N. (2001). A guide to Turkish reading and writing education (7th ed.). Ankara: Alperen Publications.

Arslan, A. (2013). Listening comprehension levels of grade seven students in terms of various variables. Journal of Language and Literature Education, 2(5), 61-81.

Aydin Yilmaz, Z. (2007). Teaching Turkish to classroom teachers. Ankara: Nobel Publication Distribution.

Aytan, T. (2011). The effects of active learning techniques on listening ability (Unpublished doctoral dissertation). Selcuk University, Konya., Turkey.

Badian, N. A. (1999). Reading disability defined as a discrepancy between listening and reading comprehension: A longitudinal study of stability, gender differences, and prevalence. Journal of Learning Disabilities, 32(2), 138-148. doi:10.1177/002221949903200204

Bilgin, M. (2013). From meaning to expression in Turkish (3rd ed.). Ankara: Ani Publishing.

Bostanci, E., \& Ceran, D. (2015). The effect of selective listening method on listening comprehension skills of 6th grade students. The Journal of International Social Research, 8(41), 909-918.

Brand-Gruwel, S., Aarnoutse, C. A. J., \& Van Den Bos, K. P. (1998). Improving text comprehension strategies in reading and listening settings. Learning and Instruction, 8(1), 63-81. doi:10.1016/S0959-4752(97)00002-9

Bulut, B. (2013). The effect of active listening training on listening comprehension, reading comprehension and vocabulary (Unpublished master's thesis). Adnan Menderes University, Aydin, Turkey.

Carlisle, J. F., \& Felbinger, L. (1991). Profiles of listening and reading comprehension. Journal of Educational Research, 84(6), 345-354. doi:10.1080/00220671.1991.9941815

Celenk, S. (2007). First reading and writing program (6th ed.). Ankara: Maya Academy.

Celepoglu, A. (2015). Listening. In L. Beyreli (Ed.), Written and oral expression (8th ed.). Ankara: Pegem Academy.

Ceran, D. (2015). The effect of selective listening and listening methodses by note-taking on listening comprehension skill of sixth grade students. Zeitschrift fur die Welt der Turken/Journal of World of Turks, 7(1), 205-219.

Cohen, J. (1988). Statistical power analysis for the behavioral sciences (2nd ed.). New York: Academic Press.

Coyne, M. D., Zipoli Jr., R. P., Chard, D. J., Faggella-Luby, M., Ruby, M., Santoro, L. E., \& Baker, S. (2009). Direct instruction of comprehension: Instructional examples from intervention research on listening and reading comprehension. Reading and Writing Quarterly, 25(2), 221-245. doi:10.1080/10573560802683697

Crain-Thoreson, C. (1996). Phonemic processes in children's listening and reading comprehension. Applied Cognitive Psychology, 10(5), 383-401. doi:10.1002/(SICI)1099-0720(199610)10:5<383::AID-ACP394>3.0.CO;2-V

Creswell, J. W. (2012). Educational research: planning, conducting, and evaluating quantitative and qualitative research ( $4^{\text {th }}$ ed.). Boston: Pearson Education, Inc.

Demirel, 0., \& Sahinel, M. (2006). Teaching Turkish (7th ed.). Ankara: Pegem A Publishing.

Diakidoy, I. N., Stylianou, P., Karefillidou, C., \& Papageorgiou, P. (2005). The relationship between listening and reading comprehension of different types of text at increasing grade levels. Reading Psychology, 26(1), 55-80. doi:10.1080/02702710590910584 
Dogan, Y. (2013). Listening education: theory, practice, measurement and evaluation. In A. Guzel, \& H. Karatay (Eds.), Turkish instruction manual (pp. 151-180). Ankara: Pegem Academy.

Dogan, Y. (2016). Listening education (4th ed.). Ankara: Pegem Academy.

Erdogan, O. (2013). Understanding comprehension skills during first reading and writing teaching. In S. Celenk (Ed.), First reading and writing program and teaching (pp. 137-161). Ankara: Egiten Book.

Gocer, A. (2017). Turkish special teaching methods (Improved 2nd edition). Ankara: Pegem Academy.

Gunes, F. (2007). Sound based sentence method and mental configuration. Ankara: Nobel Publication Distribution.

Gurgen, I. (2008). Listening learning area. In H. Pilanci (Ed.). Teaching Turkish (pp. 47-66). Eskisehir: Anadolu University Publication.

Hayes, D. (2010). Encyclopedia of primary education. Oxon: Routledge.

Hedrick, W. B. \& Cunningham, J. W. (1995). The relationship between wide reading and listening comprehension of written language. Journal of Reading Behavior, 27(3), 425-438.

Kavcar, C., Oguzkan, F., \& Sever, S. (1998). Teaching Turkish. Ankara: Engin Publishing House.

Kaya, D. (2018). Listening education. In M. Yilmaz (Ed.), Turkish teaching in the light of new developments (Updated 2nd Edition) (pp. 17-43). Ankara: Pegem Academy.

Kintsch, W., \& Kozminsky, E. (1977). Summarizing stories after reading and listening. Journal of Educational Psychology, 69(5), 491-499.

Koc, S., \& Muftuoglu, G. (1998). Teaching listening and reading. In S. Topbas (Ed.). Teaching Turkish (pp. 53-70). Eskisehir: Anadolu University Publications.

Koc, S. (2008). Oral expression. In S. Odaci (Ed.). Language and expression (pp. 413-532). Konya: Tablet Publications.

Lehto, E. J., \& Anttila, M. (2003). Listening comprehension in primary level grades two, four and six. Scandinavian Journal of Educational Research, 47(2), 133-143. doi:10.1080/00313830308615

Lundsteen, S. W. (1979). Listening: its impact at all levels on reading and the other language arts (revised edition). Urbana: National Council of Teachers of English.

McMillan J. H., \& Schumacher, S. (2006). Research in education: evidence-based inquiry (6th ed.). Boston: Pearson Education, Inc.

Ministry of National Education. (2006). Elementary Turkish course (6th, 7th, 8th grades) curriculum. Ankara.

Ministry of National Education. (2009). Elementary Turkish course curriculum and guide (grades 1 - 5). Ankara: State Books Directorate Printing House.

Ozbay, M., \& Cetin, D. (2011). The significance of prosodic awareness in improving listening skills. Mugla University Journal of Institute of Social Sciences, (26), 155-175.

Sahin, A. (2011). A study on 6th grade students' self-awareness on listening skills according to their socio-economic level. Cankiri Karatekin University Journal of Instıtute of Social Sciences, 2(1), 178-188.

Sevim, 0., \& Turan, L. (2017). The effects of drama activities on the listening and speaking skills of the sixth-grade students. Ataturk University Journal of Kazım Karabekir Education Faculty, (35), 1-13.

Sinatra, G. M. (1990). Convergence of listening and reading processing. Reading Research Quarterly, 25(2), 115-130. doi:10.2307/747597

Smith, E. E., \& Kosslyn, S. M. (2017). Cognitive psychology (Translation from first edition) (M. Sahin Trans. Ed.). Ankara: Nobel Academic Publishing.

Temple, C., \& Gillet, J. W. (1985). Language arts: learning processes and teaching practices (2nd ed.). London: Scott, Foresman and Company.

Tompkins, G. E., \& Hoskisson, K. (1995). Language arts: content and teaching strategies (3rd ed.). New Jersey: PrenticeHall. Inc.

Tuzel, S., \& Keles, E. (2013). The effects of pre and post listening questions on the listening comprehension levels of 5th grade students. Mustafa Kemal University Journal of Social Sciences Institute, 10(23), 27-45.

Ungan, S. (2014). Listening education. In A. Kirkkilic, \& H. Akyol (Eds), Teaching Turkish in primary education (4th ed.) (pp. 135-161). Ankara: Pegem Academy. 
Yalcin, A. (2002). Turkish teaching methods. Ankara: Akcag Publications.

Yaylı. D., Susar Kirmizi, F., Akkaya, N., Dogan, B., Arslan, D., \& Deliveli, K. (2008). Teaching Turkish with activities (pp. 75101). Bursa: Ekin Printing Publication Distribution.

Yildirim, K., Yildiz, M., Ates, S. \& Rasinski, T. (2010). Fifth-grade Turkish elementary school students' listening and reading comprehension levels with regard to text types. Educational Sciences: Theory and Practice, 10(3), 18791891.

Yildiz, N., \& Cecen, M. A. (2015). The effect of the listening source on listening comprehension skills of the sixth grade students. Journal of Language and Literature Education, (15), 120-133.

Yuksel, A. H. (2013). Speaking and listening. In U. Demiray (Ed.), Effective communication (6th ed.) (pp. 133-188). Ankara: Pegem Academy.

Yuksel, A. H. (2015). Speaking and listening in effective communication. In E. Eroglu, \& A. H. Yuksel (Eds.), Effective communication techniques (3rd ed., pp. 106-141). Eskisehir: Anadolu University Press. 